\title{
MODELLING SPATIAL CHANGES IN COASTAL AREAS OF SAMSUN (TURKEY) USING A CELLULAR AUTOMATA-MARKOV CHAIN METHOD
}

\author{
Derya Ozturk
}

Original scientific paper The evolution of cities over a specific time period and the determination of relevant trends are important to simulate for the proper development and planning of a city. In particular, coastal areas experience intense pressure from developers with respect to settlements, tourism, trade and industry, and built-up areas are being observed near coasts. The inability to direct development and control growth is destroying natural resources in coastal areas at a rapid pace. Thus, determining these trends is the key component for ensuring the protection of natural resources and planned growth. Because a complete estimation of urban expansion is not possible, likely changes can be determined using simulations. In this study, a 30-year urban expansion simulation (2004-2034) was obtained using land use/land cover (LU/LC) data for 1987 and 2004 at Samsun (Turkey) coastal areas and using the Cellular AutomataMarkov Chain (CA-Markov) method. To verify the method, urban expansion simulation for the year 2014 was compared with real LU/LC data for the same year, and the kappa value was found to be 0,82. To determine LU/LC, Landsat TM/ETM+/OLI satellite images were used, and the analyses were realised in a geographic information system (GIS) environment. As a result of the study, the CA-Markov Chain approach integrated with GIS and remote sensing was shown to be effective in the study of urban growth dynamics. Using the simulation for the year 2034, probable urban expansion in the 20142034 period was estimated as approximately 3683 ha and the probable destructions of absolute agricultural lands, forests and pastures were predicted as approximately 968 ha, 228 ha and 24 ha, respectively.

Keywords: cellular automata; GIS; Markov Chain; remote sensing; urban expansion

\section{Modeliranje prostornih promjena u priobalnim područjima Samsuna (Turska) primjenom metode Stanični automati-Markovljev lanac}

Izvorni znanstveni članak

Promjene gradova kroz određeni vremenski period i određivanje relevantnih trendova važni su za simuliranje odgovarajućeg razvoja i planiranja grada. U priobalnim područjima naročito dolazi do izražaja intenzivni pritisak za izgradnjom, razvojem turizma, trgovine i industrije od strane velepoduzetnika, institucija i poduzeća koja se bave izgradnjom. Zbog nesposobnosti usmjeravanja razvoja i jačanja kontrole ubrzano dolazi do uništavanja prirodnih resursa u priobalnim područjima. Stoga je određivanje tih trendova ključno za osiguranje zaštite prirodnih resursa i planiranog razvoja. Budući da nije moguća potpuna procjena urbanog širenja, vjerojatne se promjene mogu odrediti simulacijama. U ovom se radu simulacija 30 -godišnjeg urbanog širenja (2004-2034) dobila prema podacima o korištenju zemljišta/izgrađenosti zemljišta - land use/land cover (LU/LC) iz 1987 i 2004 za Samsun, priobalna područja Turske, uz primjenu metode Stanični automati-Markovljev lanac (CA-Markov). Kako bi se provjerila ta metoda, simulacija urbanog širenja za 2014. uspoređena je sa stvarnim LU/LC podacima za istu godinu te je dobivena kappa vrijednost od 0,82. Za određivanje LU/LC korištene su satelitske slike, a analize su izvršene u okruženju geografskog informacijskog sustava (GIS). Pokazalo se da je pristup CA-Markovljev lanac integriran s GIS i daljinskim očitavanjem učinkovit $u$ analizi dinamike urbanog rasta. Primjenom simulacije za 2034. godinu, vjerojatnost urbanog širenja u periodu 20142034 procijenjena je kao približno 3683 ha, a predviđeno je vjerojatno uništenje apsolutno poljoprivrednog zemljišta, šuma i pašnjaka od približno 968 ha, odnosno 228 ha i 24 ha.

Ključne riječi: daljinsko očitavanje; GIS; Markovljev lanac; stanični automati; urbano širenje

\section{Introduction}

Simulation models are important in determining urban and rural trends and in planning studies [1, 2]. Estimations of future growth and of trends in land use/land cover (LU/LC) are important for planning purposes, particularly in sensitive coastal areas, where changes occur very rapidly due to expansion pressure [3, 4].

Simulation approaches based on geographic information systems (GIS) are used in studies related to spatial and temporal processes. The integration of GIS and Cellular Automata (CA) has attracted attention in recent years, particularly regarding simulations of urban expansion, transportation and forest fires [5]. The CA method is a system used in the division of facts or in defining issues by cell and in the determination of the future status of each cell based on neighbouring cells $[6$, 7]. CA comprises four elements; cell space, cell states, time steps and transition rules [8]. A Markov Chain is a stochastic process that defines the transition probabilities from one state to another state using a simple sequential procedure. Markov Chain is an iterative procedure and a next status at $t+1$ is based only on the previous status at $t$ $[9,10]$.

Contiguity is one of the main geospatial elements that cause numerous change dynamics [2]. When an area in one class is close to areas in another class, the area shows a high tendency to transform into that class, this change tendency is referred to as the expansion phenomenon [11]. Markov Chain is a practical method but a disadvantage of Markov Chain analysis is that it is nonspatial, meaning that it does not consider spatial location explicitly in the predicting LU/LC conversion and requires additional assumptions for allocation $[8,12]$.

Despite the fact that the Markov Chain method lacks a spatial component $[2,13]$, in the CA method, future status of a cell can be estimated by the current state of a cell and changes in those of its neighbours $[8,13]$. That is, LU/LC change can be composed based on the principles of continuation of historical alterations and result of neighbourhood interaction [8]. The integration of these two methods provides an assessment based on both the spatial relations and past status in the simulation of future statuses [13]. In a hybrid CA-Markov Chain model, the Markov Chain process determines temporal dynamics of LU/LC categories based on transition probabilities, while 
the spatial dynamics is arranged by local rules determined by CA spatial filter and transition potentials [14].

In a hybrid CA-Markov Chain model, future transition probabilities are calculated using LU/LC layers at $\mathrm{t} 1$ and $\mathrm{t} 2$ ( $\mathrm{t} 1$ : earlier date, $\mathrm{t} 2$ : later date), and the temporal dynamics between LU/LC classes are determined using transition probabilities. For future projection, LU/LC layer at $\mathrm{t} 2$ is accepted as base layer and the transition areas produced by the Markov Chain and the transition-potential layers (suitability layers) for each LU/LC class are used $[11,15]$.

The transition-potential layers specify the degree to which each cell is suitable for each of the LU/LC types [15]. In the CA-Markov Chain scheme, the process of spatially projecting the LU/LC continues iteratively until the total area determined by the Markov Chain is obtained [11].

In this study, the spatial usage changes in coastal areas of Samsun's central districts that show rapid growth and urban expansion were simulated using the CAMarkov Chain method. Although numerous studies to determine existing LU/LC and temporal changes in the LU/LC in Samsun have been conducted [16-23], few studies have been published regarding the urban LU/LC changes [15]. In this study, considering the LU/LC for the years 1987 and 2004, an urban expansion simulation for the year 2034 was obtained for the 30-year period starting in 2004, and the trends, magnitudes and spatial distributions of the changes were determined. Moreover, a 10 -year simulation ending in 2014 was used to compare 2014 results with the LU/LC for the same year, and the accuracy and validity of the method were inspected. The risks of destroying agricultural land, forests and pastures due to urbanisation between 2014 and 2034 were determined.

\section{Study Area}

Samsun is one of the oldest settlements along the coast of the Black Sea. The coasts of urban areas have been subjected to human intervention since ancient times. These coasts, which maintained their natural features until the middle of the 20th century, have faced very important changes in the last 50 years due to intensified settlement pressure from urbanisation, population growth, socioeconomic development and space constraints. During this period, particularly in the 1990s, the increased development of summer houses and sites west of the city centre caused rapid anthropogenic changes that expanded outward from the city centre. The east side of the city exhibits industrial-focused development [22].

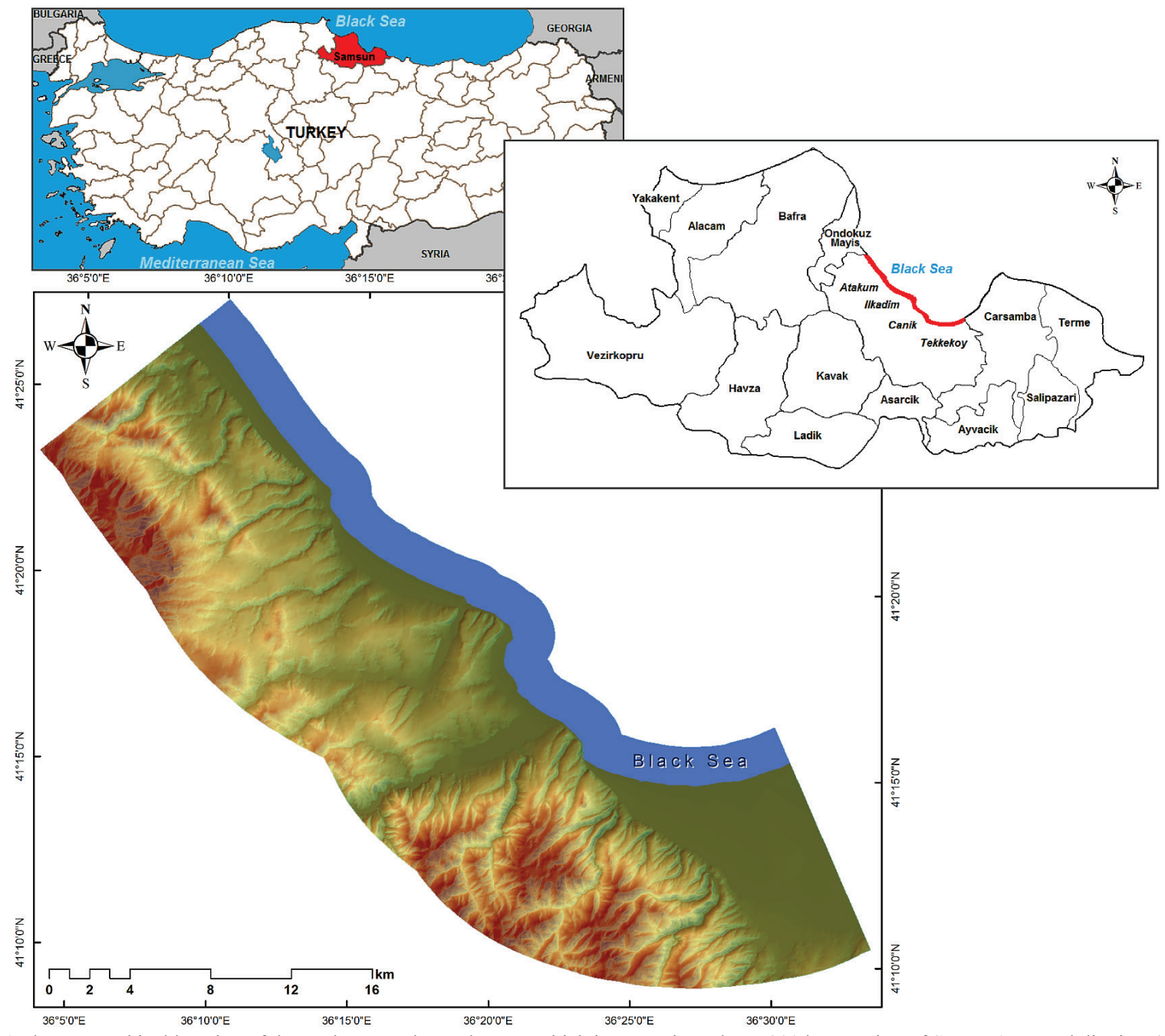

Figure 1 The geographical location of the study area. The study area, which is approximately 55200 ha, consists of Samsun's central districts (Atakum, Ilkadim, Canik, and Tekkekoy) 
In this study, the coasts of Samsun, where the development is the most intense, were examined. The literature suggests that it is difficult to devise a general definition of a coastal area (or coastal zone) and that the definition of a coastal area may change depending on the purpose of the study. For instance, whereas a $3-\mathrm{km}$ landward area from the coast is classified as a coastal area in planning studies in Denmark (1991), a 200-m landward area is classified as a coastal area in planning studies in Spain (1988) [24]. According to Turkey's laws and legislation regarding coasts, there is no definition of a "coastal area". The definition of "coast" is given as "the area in between the coastline and coast edge line" in Turkish Coastal Law and the Turkish Regulation on the Enforcement of Coast Law. In the same legislation, the coastal stretch was defined as "the area with a horizontal width of at least 100 metres in the direction of land as from the coast edge line of seas and natural lakes".

In this context, coastal area can be defined as an area that is in interaction with coast and needs to be addressed as integrated with coast in terms of topographical, ecological, tourism, urbanisation and industrialisation properties. Therefore, coastal area should be dealt with separately for each coast in line with the principles of sustainable development.

In this study, the coastal area was classified as the landward area of $10 \mathrm{~km}$ and the seaward area of $2 \mathrm{~km}$ from the coastal edge, considering the current status of Samsun's central districts and their future development potential. The coastal length is approximately $45 \mathrm{~km}$ in the following municipalities: Atakum District Municipality (formerly Atakum, Atakent, Kurupelit, Altinkum, Catalcam and Taflan First Tier Municipalities), Ilkadim District Municipality (formerly Ilkadim and Gazi First Tier Municipalities), Canik District Municipality (formerly Canik First Tier Municipality) and Tekkekoy District Municipality (formerly Tekkekoy and Kutlukent Municipalities) (Fig. 1).

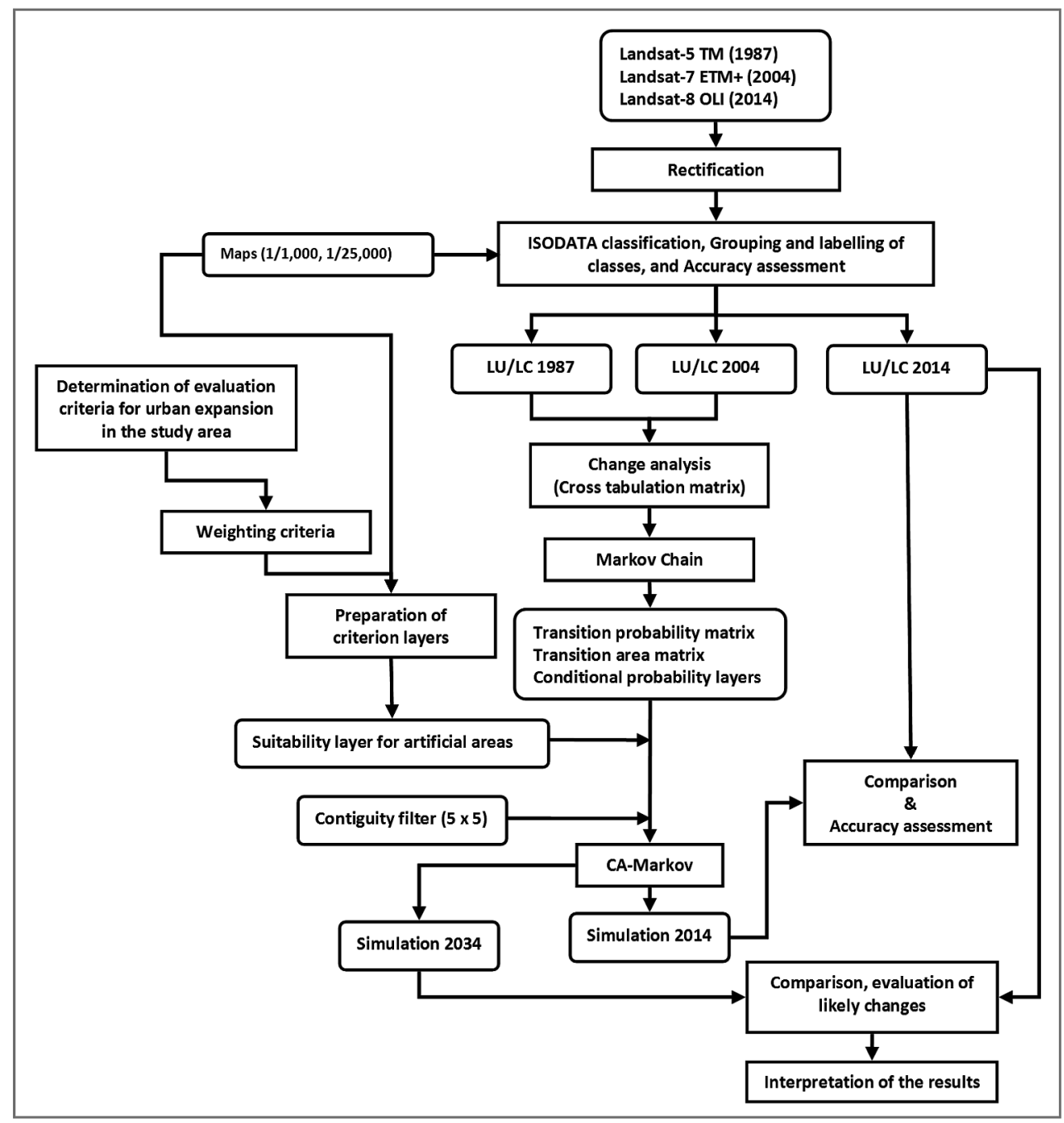

Figure 2 Workflow of the main steps of the study. In the first stage, the LU/LC of the years 1987, 2004, and 2014 were determined using Landsat satellite images and maps. The CA-Markov Chain method was used to simulate the changes in the LU/LC for the years 2014 and 2034.

\section{Data and methods}

To determine the LU/LC, 1987-07-20 Landsat TM, 2004-05-07 Landsat ETM+ and 2014-08-31 Landsat OLI images (Path/Row: 175/31) were used. Using LU/LC data for the years 1987 and 2004, a 30-year urban expansion simulation through the year 2034 was performed using the CA-Markov Chain method. Moreover, to verify the methodology, a 10-year simulation ending in 2014 was obtained to compare the results with the LU/LC data for 
2014. The methodology used in this study is presented in Fig. 2. To process the satellite images and to simulate urban expansion, the IDRISI 17.0 Selva software (Clark Labs, Clark University, Worcester, MA, USA) and to perform GIS analysis, ArcGIS 10.0 software (Esri, Redlands, CA, USA) was used.

The determination of the LU/LC for the years 1987, 2004, and 2014 and the changes during 1987-2004 are explained in Section 3.1, the calculations of the transition probabilities and transition areas are presented in Section 3.2., the composition of transition-potential layers is explained in Section 3.3, and finally, the implementation of the CA-Markov Chain Method for the urban expansion simulation is explained in detail in Section 3.4.

\subsection{Determination of LU/LC}

To model the changes in the LU/LC and future urban expansion in coastal areas of the central Samsun districts, the LU/LC layers were produced using the Landsat images. Landsat images were rectified using 1/25 000scale topographic maps and 1/1000-scale base maps. During these processes, the mean square error was less than 0,5 pixels: the errors were 0,188 pixels for the year 2014, 0,197 pixels for the year 2004 and 0,285 pixels for the year 1987. Following the rectification, the images were classified using the Iterative Self-organizing Data Analysis Technique (ISODATA) (all bands were used except for the thermal band due to the spatial resolution). ISODATA classes are identified solely on basis of spectral characteristics [25]. Thus, some spectral classes may contain more than one LU/LC class and/or one LU/LC class may be related to more than one spectral class [26]. Selection of spectral class number is important for analysis quality, because different number of class results in different partitions [27]. However, the optimal number of spectral classes to specify is usually unknown. Therefore, conservatively high number is selected at first and results are analyzed and the function is rerun with a reduced number of classes [28]. In this study, the minimum number of spectral class with the best class separation was determined by reducing from 40 to 20 . Following the classification, the classes were grouped and categorised into three classes: artificial areas (settlement, trade, industry etc.), water bodies and other areas, depending on the purpose of the study.

To determine the accuracy of the classification, 100 reference points were selected for each class through visual interpretation of the images and maps, and error matrixes were constructed. The kappa value was determined to be 0,89 for the year $1987,0,92$ for the year 2004 and 0,90 for the year 2014. The magnitude of the changes of the LU/LC classes for the years 1987 and 2004 are shown in Tab. 1, and the classification results and change areas are in Fig. 3.
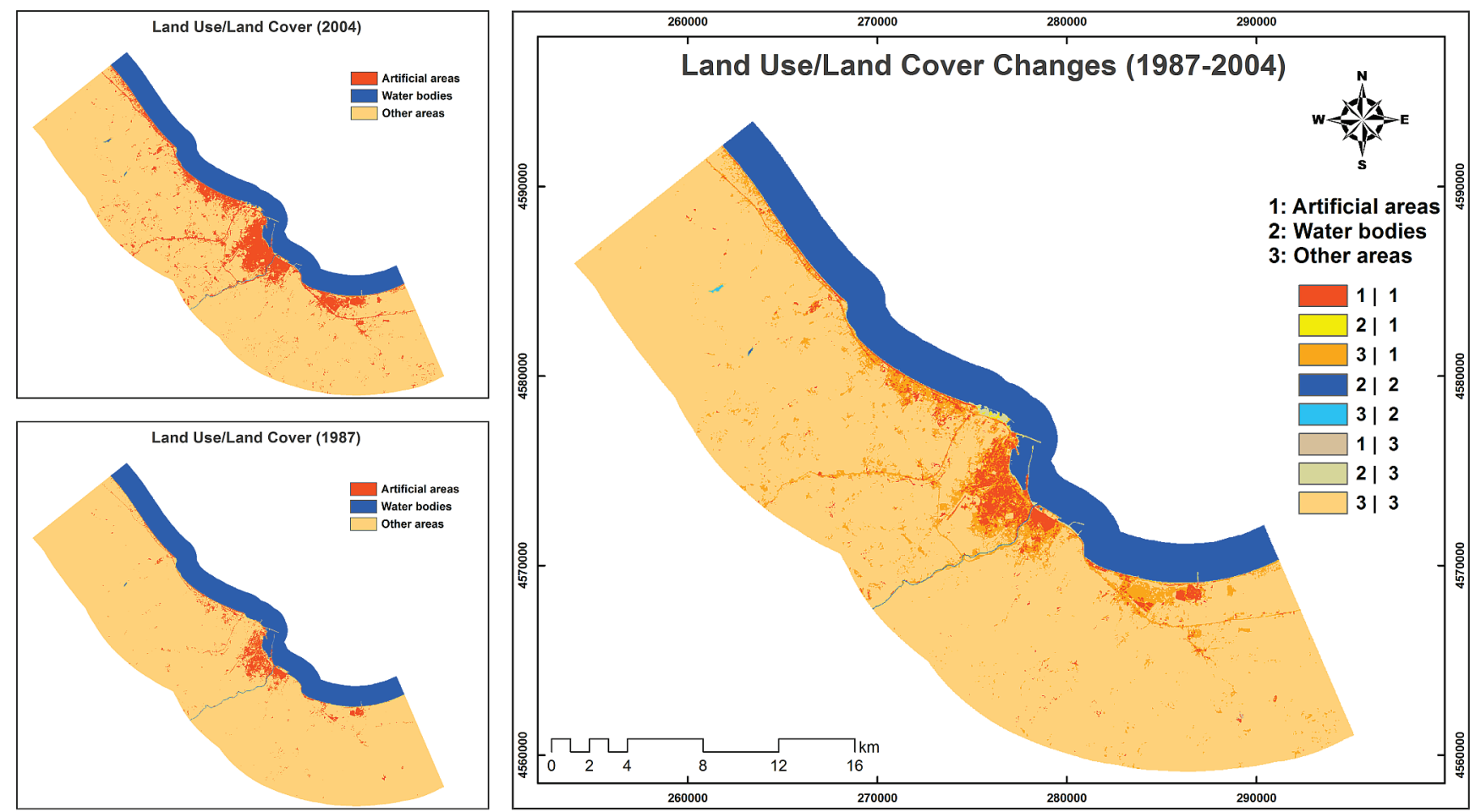

Figure $3 \mathrm{LU} / \mathrm{LC}$ for the years 1987 and 2004 and the change in the LU/LC during the 1987-2004 period, when the transition to artificial areas is obvious.

Table 1 Areal (ha) comparison of LU/LC for the years 1987 and 2004

\begin{tabular}{|c|c|c|c|c|c|}
\hline & \multicolumn{4}{|c|}{2004} \\
\hline & & Artificial areas & Water bodies & Other areas & Total \\
\hline \multirow{4}{*}{1987} & Artificial areas & 1489,59 & 0,00 & 3,78 & 1493,37 \\
\hline & Water bodies & 15,75 & 8085,96 & 130,50 & 8232,21 \\
\hline & Other areas & 3165,57 & 10,35 & 42287,49 & 45463,41 \\
\hline & Total & 4670,91 & 8096,31 & 42421,77 & 55188,99 \\
\hline
\end{tabular}




\subsection{Calculation of transition probabilities and transition areas}

The transition probability matrix indicates the timedependent transition probability of each LU/LC class transforming to another class. The transition area matrix shows the area expected to change over a period from each LU/LC class to other LU/LC classes. This matrix is obtained by multiplying the transition probability matrix with the areas of the LU/LC classes at the base date [11, 29]. Regarding the study area (using LU/LC layers for the years 1987 and 2004), the transition probability matrix and transition area matrix for the year 2034, with a 30 year period starting in 2004, are shown in Tab. 2 and Tab. 3 , respectively. The transition probability matrix for the year 2014 over a 10-year period is shown in Tab. 4, and the transition area matrix is shown in Tab. 5.

Table 2 Transition probability matrix for the 30-year period (ending in 2034)

\begin{tabular}{|c|c|c|c|c|}
\hline & Artificial areas & Water bodies & Other areas & Total \\
\hline Artificial areas & 0,9658 & 0,0000 & 0,0342 & 1,0000 \\
\hline Water bodies & 0,0079 & 0,9398 & 0,0523 & 1,0000 \\
\hline Other areas & 0,1458 & 0,0005 & 0,8537 & 1,0000 \\
\hline
\end{tabular}

Table 3 Transition area (ha) matrix for the 30 -year period (ha) (ending in 2034)

\begin{tabular}{|c|c|c|c|c|}
\hline & Artificial areas & Water bodies & Other areas & Total \\
\hline Artificial areas & 4511,16 & 0,00 & 159,75 & 4670,91 \\
\hline Water bodies & 63,99 & 7608,87 & 423,45 & 8096,31 \\
\hline Other areas & 6185,07 & 21,24 & 36215,46 & 42421,77 \\
\hline Total & 10760,22 & 7630,11 & 36798,66 & 55188,99 \\
\hline
\end{tabular}

Table 4 Transition probability matrix for the 10-year period (ending in 2014)

\begin{tabular}{|c|c|c|c|c|}
\hline & Artificial areas & Water bodies & Other areas & Total \\
\hline Artificial areas & 0,9685 & 0,0000 & 0,0315 & 1,0000 \\
\hline Water bodies & 0,0037 & 0,9598 & 0,0365 & 1,0000 \\
\hline Other areas & 0,0703 & 0,0002 & 0,9294 & 1,0000 \\
\hline
\end{tabular}

Table 5 Transition area (ha) matrix for the 10-year period (ending in 2014)

\begin{tabular}{|c|c|c|c|c|}
\hline & Artificial areas & Water bodies & Other areas & Total \\
\hline Artificial areas & 4523,94 & 0,00 & 146,97 & 4670,91 \\
\hline Water bodies & 29,97 & 7771,05 & 295,29 & 8096,31 \\
\hline Other areas & 2983,41 & 9,81 & 39428,55 & 42421,77 \\
\hline Total & 7537,32 & 7780,86 & 39870,81 & 55188,99 \\
\hline
\end{tabular}

Table 6 Determination of criterion weights using the AHP

\begin{tabular}{|l|c|c|c|c|c|c|}
\hline Criteria & $\begin{array}{c}\text { Proximity to } \\
\text { tram routes }\end{array}$ & $\begin{array}{c}\text { Proximity to } \\
\text { settlement/trade/ } \\
\text { industry areas }\end{array}$ & $\begin{array}{c}\text { Proximity to } \\
\text { major roads }\end{array}$ & $\begin{array}{c}\text { Proximity to } \\
\text { coast }\end{array}$ & Slope & Weights \\
\hline Proximity to tram routes & 1 & 2 & 2 & 3 & 4 & 0,380 \\
\hline Proximity to settlement/trade/industry areas & 0,5 & 1 & 1 & 2 & 3 & 0,219 \\
\hline Proximity to major roads & 0,5 & 1 & 1 & 2 & 2 & 0,201 \\
\hline Proximity to coast & 0,333 & 0,5 & 0,5 & 1 & 1 & 0,107 \\
\hline Slope & 0,25 & 0,333 & 0,5 & 1 & 1 & 0,093 \\
\hline$C R=0,007$ & & & & $\Sigma=1$ \\
\hline
\end{tabular}

\begin{tabular}{|c|c|c|c|c|c|c|c|c|c|}
\hline $\begin{array}{l}\text { Proximity to } \\
\text { tram routes }(\mathrm{m})\end{array}$ & Score & $\begin{array}{c}\text { Proximity to } \\
\text { settlement/trade/ } \\
\text { industry areas (m) }\end{array}$ & Score & $\begin{array}{l}\text { Proximity to } \\
\text { major roads } \\
(\mathrm{m})\end{array}$ & Score & $\begin{array}{l}\text { Proximity to } \\
\text { coast }(\mathrm{m})\end{array}$ & Score & $\begin{array}{l}\text { Slope } \\
(\%)\end{array}$ & Score \\
\hline$<100$ & 1,0 & $<100$ & 1,0 & $<100$ & 1,0 & $<100$ & 1,0 & $0-3$ & 1,0 \\
\hline $100-200$ & 0,9 & $100-200$ & 0,9 & $100-200$ & 0,9 & $100-200$ & 0,9 & $3-6$ & 0,9 \\
\hline $200-300$ & 0,8 & $200-300$ & 0,8 & $200-300$ & 0,8 & $200-300$ & 0,8 & $6-10$ & 0,7 \\
\hline $300-400$ & 0,7 & $300-400$ & 0,7 & $300-400$ & 0,7 & $300-400$ & 0,7 & $10-15$ & 0,5 \\
\hline $400-500$ & 0,6 & $400-500$ & 0,6 & $400-500$ & 0,6 & $400-500$ & 0,6 & $15-20$ & 0,2 \\
\hline $500-700$ & 0,5 & $500-600$ & 0,5 & $500-700$ & 0,5 & $500-700$ & 0,5 & $>20$ & 0,1 \\
\hline $700-1000$ & 0,4 & $600-800$ & 0,3 & $700-1000$ & 0,4 & $700-1000$ & 0,4 & & \\
\hline $1000-1500$ & 0,2 & $800-1000$ & 0,2 & $1000-1500$ & 0,2 & $1000-1500$ & 0,3 & & \\
\hline \multirow[t]{2}{*}{$>1500$} & 0,1 & $>1000$ & 0,1 & $>1500$ & 0,1 & $1500-2000$ & 0,2 & & \\
\hline & & & & & & $>2000$ & 0,1 & & \\
\hline
\end{tabular}

\subsection{Composition of transition-potential layers}

In determining the transition potential for artificial areas, parameters defining the urban expansion observed between 1987 and 2004 and factors that will cause changes in the features were considered. The transitionpotential layer for artificial areas was composed with Multiple Criteria Decision Analysis (MCDA) using the 
Analytic Hierarchy Process (AHP) [30] by assessing various criteria, such as the proximity to tram routes, proximity to major roads, proximity to settlement/trade/industry areas, proximity to coast, and slope. For water bodies and other areas, conditional probability layers obtained using the Markov process were used as the transition-potential layer (Fig. 4). Pairwise comparisons [31] were used to determine the criteria weights in the composition of the transition- potential layer for artificial areas, and the calculated weights of the criteria are provided in Tab. 6. The consistency ratio (CR) was 0.007 , and the pairwise comparisons are consistent because this value is smaller than 0.10. A rating method was used for each criterion layer. For each evaluation criterion, the criterion values were based on scores that varied between 0 and 1 (Tab. 7).
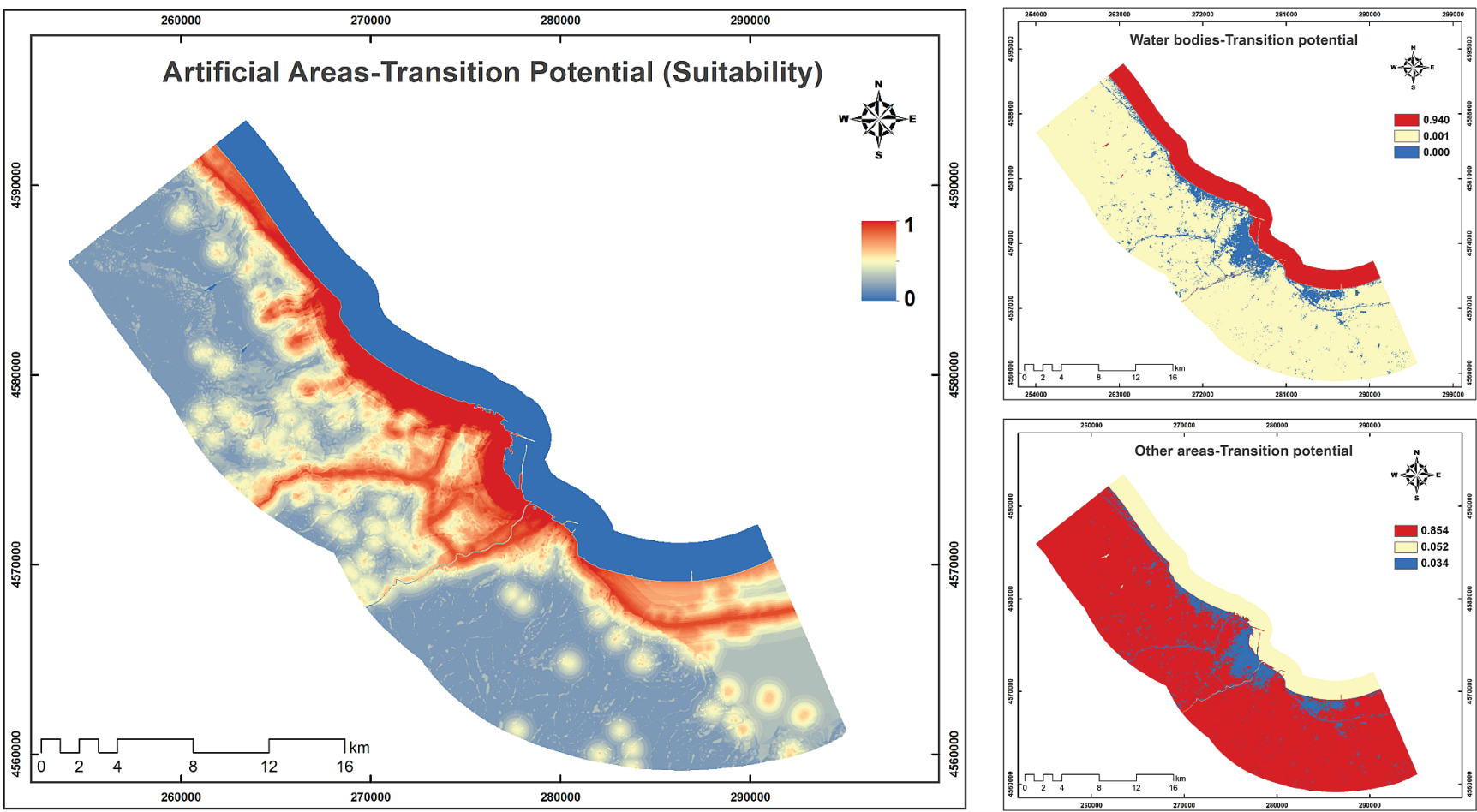

Figure 4 Transition-potential layers. Because the focus of the study is urban expansion, the transition potential for artificial areas was determined using a suitability analysis with MCDA. Therefore, AHP was used for the artificial areas. For the classes of water bodies and other areas, Markov conditional probability images based on the probability of each class while considering past experiences were used as transition-potential layers.

\subsection{Implementation of CA-Markov chain method for urban expansion simulation}

In the CA-Markov Chain method, the allocation of cells for each LU/LC continues iteratively [15] until the process distributes the estimated quantity of change (transition areas) [2]. The number of iterations is based on the number of time steps (from the base date to the projection date) [11].

The CA-Markov Chain uses a contiguity filter to develop a spatially explicit contiguity-weighting factor to change the cells based on its previous state and those of its neighbours [13]. In this study, a $5 \times 5$ contiguity filter (Eq. (1)) which has been extensively used to simulate urban expansion $[13,15,29,32]$ was applied to transitionpotential layers. However, the filter can be changed depending on the purpose of the study and analyst's preference/decision [29, 33].

$$
\left[\begin{array}{lllll}
0 & 0 & 1 & 0 & 0 \\
0 & 1 & 1 & 1 & 0 \\
1 & 1 & 1 & 1 & 1 \\
0 & 1 & 1 & 1 & 0 \\
0 & 0 & 1 & 0 & 0
\end{array}\right]
$$

In this study, a 30-year urban expansion simulation was obtained (2004-2034) (Fig. 5) and a 10-year simulation was obtained (2004-2014) using data from 1987 and 2004.

\section{$4 \quad$ Results and Discussion}

Artificial areas, which were 1493 ha in 1987, reached 4671 ha in 2004 (Tab. 1). Changes in the LU/LC were examined with maps and field studies. Although areas that are close to the shores of Taflan, Catalcam, Altinkum, Kurupelit, Atakent and Atakum, comprising the west side of the study area, had developed as beach and summer housing areas in Samsun until the 1980s, significant increases in the number of primary houses and secondary houses (summer houses) occurred. As a result of the establishment of municipalities, increasing urban growth pressure, population growth, and construction of the Ondokuz Mayis University [22], the density of settlements rapidly increased. Tekkekoy and Kutlukent, which are located on the east side of Samsun, experienced particularly substantial development as an industrial zone; these areas formed as organised industrial zones, smallscale industrial sites, agricultural production facilities and non-residential urban working areas. In addition, Canik, Ilkadim and Gazi developed as settlements, trade areas, 
official working areas and partial industrial areas. A total area increase of 146 ha (Tab. 1) was achieved by filling (rock/soil fill) at the shore for parks, recreation areas, fishing ports, and yacht ports between 1987 and 2004 .

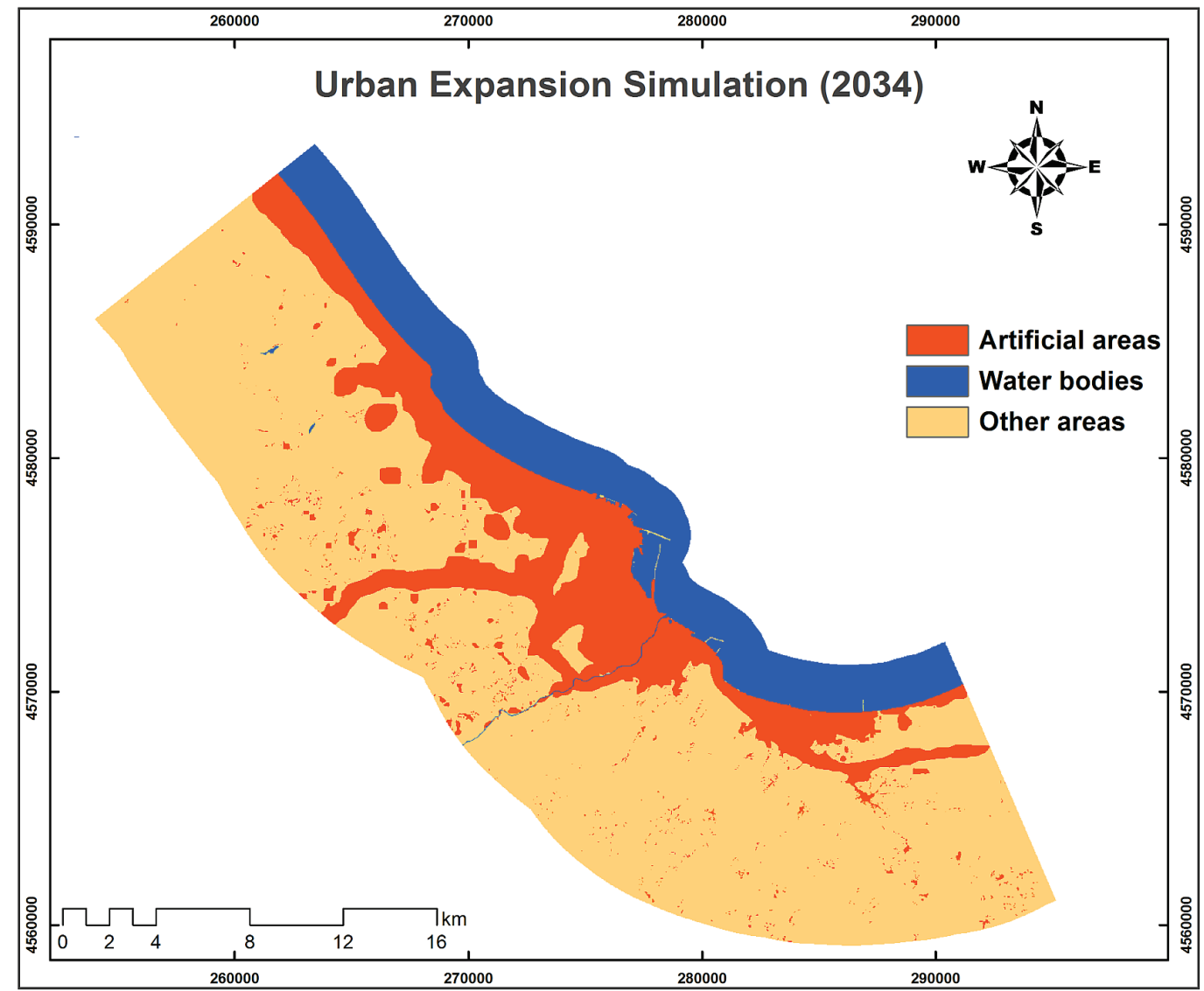

Figure 5 Urban expansion for the year 2034 based on the 30-year simulation (2004-2034)

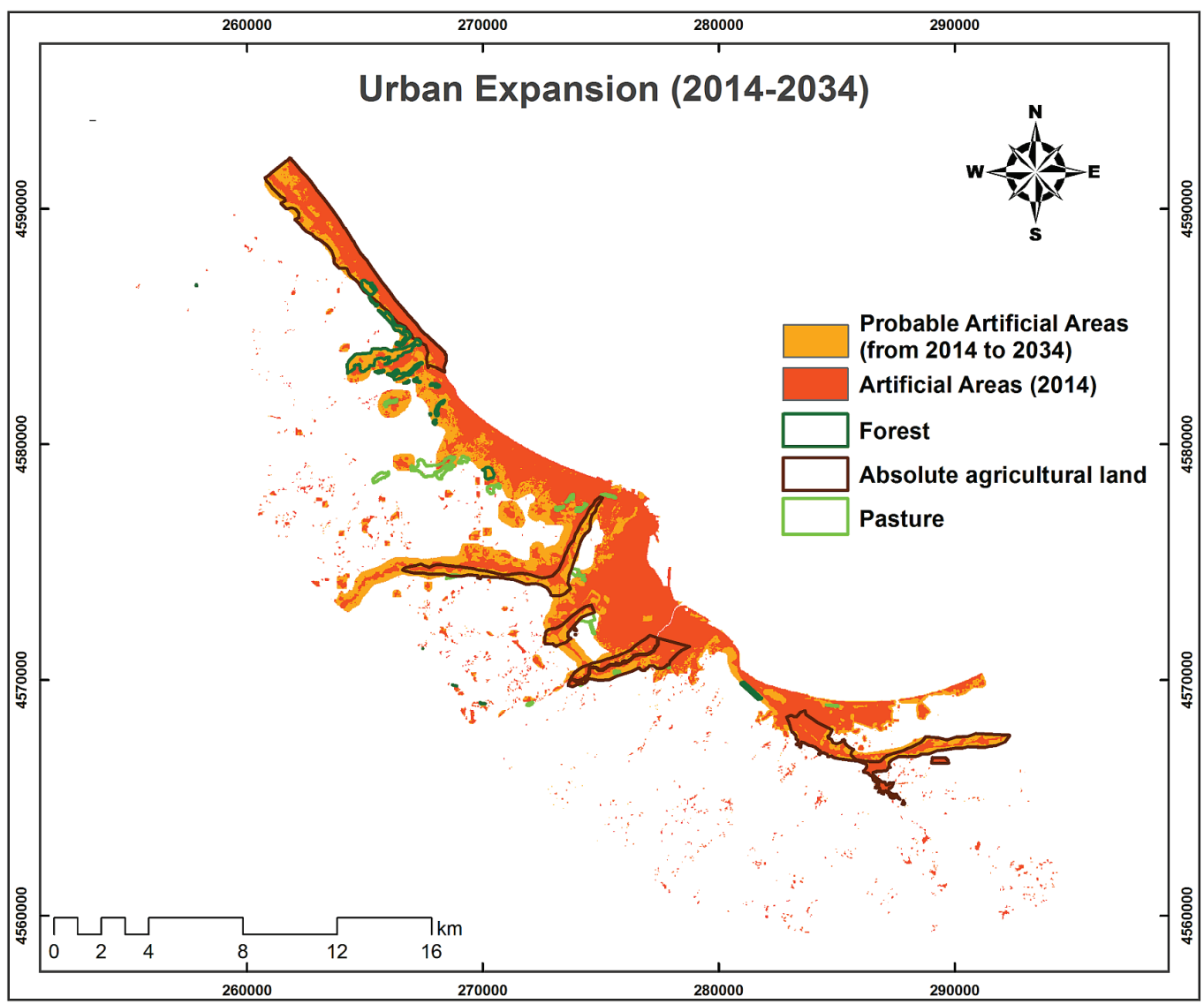

Figure 6 Urban expansion for the period of 2014-2034. The figure presents a comparison between the present and probable future situations. The transition to artificial areas can destroy forests, agricultural land and pastures. 
According to the urban expansion simulation using the CA-Markov Chain method (Fig. 5) for the year 2034, the artificial areas (4671 ha in 2004) will reach 10760 ha in 2034 (Tab. 3). Based on the likely artificial areas for the year 2034, the expansion might be realised in the form of densification and congestion at current intense settlement/trade/industry areas and along the transportation network. This change will not be a surprise. Because transport network and land use always affect each other over time [34].

To assess the validity of the results, a 10-year simulation was performed through 2014, and the results were compared with the LU/LC layer for 2014. In the comparison, the kappa value was calculated as 0,82 . The obtained accuracy was assessed based on literature surveys $[32,35,36]$ and the resolution and classification errors of satellite images used in the analyses and it was thought that the model accuracy was sufficient. Thus, the simulation performed for 2034 and the forecasts arising as the result of this simulation might provide important information for the future. The simulation for the year 2034 overlapped with the LU/LC for the year 2014, and urban expansion areas expected between 2014 and 2034 were examined. In addition, the interaction of these likely expansion areas with the natural resources was analysed (Fig. 6). Consequently, the results showed that artificial surfaces, which covered 7077 ha in 2014 (LU/LC layer for 2014), will likely cover 10760 ha in 2034 (an increase of 3683 ha associated with an urban growth at a rate of 52 $\%$ ) and until 2034, approximately 968 ha of absolute agricultural land, 228 ha of forest and 24 ha of pasture would be under the threat of transition to urban usage. The current destruction of agricultural, forest and pasture lands might continue at a rapid pace unless the growth of the city is controlled.

\section{Conclusion}

The purpose of studies that estimate future LU/LC changes and urban expansion is to obtain data that will contribute to the synthesis phase of the planning process, rather than to assert exact predictions concerning the development of a city [6]. The composition of LU/LC scenarios for a future year can be used to determine the magnitude and location of changes that may be expected and to examine possible changes and enactment of measures in planning studies when required.

In this study, the urban expansion for the year 2034 in coastal Samsun was simulated using the CA-Markov Chain approach integrated with GIS and remote sensing. To analyse the accuracy of the model, a simulation for the year 2014 was compared with the LU/LC data obtained from satellite images of the same year, and the kappa value was 0,82 .

Using the simulation for the year 2034 by overlapping with LU/LC layer for the year 2014, likely changes in urban expansion between 2014 and 2034 were determined, and the probable destruction of agricultural land, forests and pastures was presented quantitatively. An increase in the area of artificial areas from 7077 ha to 10760 ha and the destruction of 968 ha of absolute agricultural land, 228 ha of forest, and 24 ha of pasture was estimated for the 2014-2034 period. Based on the areas of changes, potentially new artificial areas might cause considerable losses of natural resources.

The success of the model is directly related to the resolution of the data and the methods used. Landsat images have a moderate resolution and classification errors have negative effects on the results; but still recent ability to freely access Landsat archive data over the internet is increasing the use of such images in a wide range of fields. This study shows that the CA-Markov Chain approach integrated with remote sensing and GIS can be used effectively in studying potential future changes and in analysing the direction, rate and spatial distribution of changes in LU/LC. Moreover, the accuracy of the simulation can be increased using high-resolution satellite images.

\section{References}

[1] Onate-Valdivieso, F.; Sendra, J. B. Application of GIS and remote sensing techniques in generation of land use scenarios for hydrological modeling. // Journal of Hydrology. 395, 3-4(2010), pp. 256-263. DOI: 10.1016/j.jhydrol.2010.10.033

[2] Arsanjani, J. J.; Helbich, M.; Kainz, W.; Boloorani, A. D. Integration of logistic regression, Markov chain and cellular automata models to simulate urban expansion. // International Journal of Applied Earth Observation and Geoinformation. 21, (2013), pp. 265-275. DOI: 10.1016/j.jag.2011.12.014

[3] Seker, D. Z.; Kaya, S.; Alkan, R. M.; Tanik, A.; Saroglu, E. 3D coastal erosion analysis of Kilyos - Karaburun region using multi-temporal satellite image data. // Fresenius Environmental Bulletin. 7, 11b(2008), pp. 1977-1982.

[4] Hua, L.; Tang, L.; Cui, S.; Yin, K. Simulating urban growth using the SLEUTH model in a coastal peri-urban district in China. Sustainability. 6, 6(2014), pp. 3899-3914. DOI: 10.3390/su6063899

[5] Liu, L.; Wang, X.; Eck, J.; Liang, J. Simulating crime events and crime patterns. // Geographic Information Systems and Crime Analysis / Wang, F. (Ed.), 2005, pp. 197-213.

[6] Yuzer, M. A; Yuzer, S. Cellular automata tabanlı LUCAM modeli ile İstanbul'un gelişim ve dönüşümüne iliş̧in makro form simülasyonları. // Journal of İstanbul Kültür University. 4, (2006), pp. 231-244. (in Turkish)

[7] Ayazli, I. E. Ulaşım Ağlarının Etkisiyle Kentsel Yayılmanın Simülasyon Modeli: 3. Boğaz Köprüsü Örneği. Doktora Tezi, Yıldız Teknik Üniversitesi, Fen Bilimleri Enstitüsü, İstanbul, 2011. (in Turkish)

[8] van Schrojentein Lantman, J.; Verbug, P. H.; Bregt, A.; Geertman, S. Core principles and concepts in land-use modelling: A literature review. // Land-Use Modelling in Planning Practice. / Koomen, E.; Borsboom-van Beurden, J. (Eds.), GeoJournal Library, 2011, Volume 101, Chapter 3, pp. 35-57.

[9] Steyvers, M. Computational Statistics with Matlab. The Web version (2011). http://psiexp.ss.uci.edu/research/ teachingP205C/205C.pdf (27.06.2015)

[10] Khodabin, M. States recognition in random walk Markov chain via binary Entropy. // Journal of Interpolation and Approximation in Scientific Computing. 2013, (2013), pp. 1-6. DOI: 10.5899/2013/jiasc-00025

[11] Eastman, J. R., IDRISI Selva Manuel. Clark University, 2012.

[12] Rainis, R.; Shariff, N. M. Methodologies in urban land use modelling in Malaysa: Current status, prospects and challenges. // Urban Ecosystem Studies in Malaysia: A 
Study of Change / Hashim, N.; Rainis, R. (Eds.), Universal Publishers, USA, 2003, pp. 7-24.

[13] Houet, T.; Hubert-Moy, L. Modelling and Projecting Landuse and Land-cover Changes with a Cellular Automaton in Considering Landscape Trajectories: An Improvement for Simulation of Plausible Future States. // EARSeL eProceedings. 5, 1(2006), 63-76.

[14] Arsanjani, J. J. Dynamic Land Use/Cover Change Modelling: Geosimulation and Multiagent-based Modelling. Springer Theses, Springer-Verlag, Heidelberg, 2012. DOI: $10.1007 / 978-3-642-23705-8$

[15] Ozturk, D. Urban growth simulation of Atakum (Samsun, Turkey) using cellular automata-Markov chain and multilayer perceptron-Markov chain models. // Remote Sensing. 7, 5(2015), pp. 5918-5950. DOI: 10.3390/rs70505918

[16] Ozturk, D. Uydu Görüntüleri Kullanılarak Arazi Kullanımı/Arazi Örtüsündeki Değişimlerin Belirlenmesi ve Samsun Örneği. Yüksek Lisans Tezi, Ondokuz Mayıs Üniversitesi, Fen Bilimleri Enstitüsü, Samsun, 2002. (in Turkish)

[17] Uzun, A. Samsun İli Kıyılarında Antropojenik Değişmeler. // TURQUA Türkiye Kuvaterner Sempozyumu V / İstanbul, 02-05 Haziran 2005. (in Turkish)

[18] Guler, M; Yomralioglu, T; Reis, S. Using Landsat data to determine land use/land cover changes in Samsun, Turkey. // Environmental Monitoring and Assessment. 127, 1-3 (2007), pp. 155-167. DOI: 10.1007/s10661-006-9270-1

[19] Sertel, E.; Findik, S.; Kaya, N.; Seker, D. Z.; Samsunlu, A. Assessment of landscape changes in the Kizilirmak Delta, Turkey, using remotely sensed data and GIS. // Environmental Engineering Science. 25, 3(2008), pp. 353361. DOI: $10.1089 /$ ees. 2006.0149

[20] Sesli, F. A. Mapping and monitoring temporal changes for coastline and coastal area by using aerial data images and digital photogrammetry: A case study from Samsun, Turkey. // International Journal of the Physical Sciences. 5, 10(2010), pp. 1567-1575.

[21] Ozturk, D.; Sisman, A.; Maras, E. E.; Sisman, Y. SamsunAtakum'da Arazi Kullanımı/Arazi Örtüsündeki Değişimlerin Uzaktan Algılama ve CBS ile Belirlenmesi. // VI. Ulusal Coğrafya Sempozyumu / Ankara, 03-05 Kasım 2010. (in Turkish)

[22] Turkish Ministry of Environment and Urban Planning. Samsun Bütünleşik Kıyı Alanları Yönetim ve Planlama Projesi-Mekansal Strateji Planı. Mekansal Planlama Genel Müdürlüğü, Ankara, 2012. (in Turkish)

[23] Dengiz, O.; Demirag-Turan, I. Uzaktan algılama ve coğrafi bilgi sistem teknikleri kullanılarak arazi örtüsü / arazi kullanımı zamansal değişimin belirlenmesi: Samsun Merkez İlçesi örneği (1984-2011). // Turkish Journal of Agricultural Research. 1, (2014), pp. 78-90. (in Turkish)

[24] Lavalle, C.; Gomes, C. R.; Baranzelli, C.; e Silva, F. B. Coastal Zones: Policy Alternatives Impacts on European Coastal Zones 2000-2050. JRC Technical Notes, 2011.

[25] Mather, P.; Koch, M. Computer Processing of RemotelySensed Images: An Introduction. John Wiley \& Sons, Chichester, 2011. DOI: 10.1002/9780470666517

[26] Lasaponara, R.; Masini, N. Pattern recognition and classification using VHR data for archaeological research. // Satellite Remote Sensing: A New Tool for Archaeology. / Lasaponara, R.; Masini, N. (Eds.), Springer-Verlag, Heidelberg, 2012, Chapter 3, pp. 65-86.

[27] Yetis, S. M. Fuzzy clustering approach for accident black spot centers determination. // Fuzzy Logic - Emerging Technologies and Applications. / Dadios, E. (Ed.), InTech, Rijeka, Croatia, 2012, pp. 83-99.

[28] ESRI, How Iso Cluster works. http://webhelp.esri.com/ arcgisdesktop/9.3/index.cfm?TopicName=How $\% 20$ Iso $\% 20$ Cluster\%20works. (26.06.2015).
[29] Eastman, J. R. IDRISI Selva Tutorial. Clark University, 2012.

[30] Saaty, T. L. The Analytic Hierarchy Process: Planning, Priority Setting, Resource Allocation. McGraw-Hill Comp., New York, 1980.

[31] Malczewski, J. GIS and Multicriteria Decision Analysis. John Wiley and Sons, New York, 1999.

[32] Baysal, G. Urban Land Use and Land Cover Change Analysis and Modeling: A Case Study Area Malatya, Turkey. Msc Thesis, Institute for Geoinformatics (IFGI), Westfälische Wilhelms-Universität, Münster, Germany, 2013.

[33] Wang, S.; Zheng, X.; Wang, L. Simulation of Precise Scale Land Use Change Based on the Markov-Cellular Automata Model // $18^{\text {th }}$ International Conference on Geoinformatics / Liu, Y.; Chen, A. (Eds.), Beijing, China, 2010, pp. 702-706.

[34] Demirel, H.; Sertel, E.; Kaya, S.; Seker, D. Z. Exploring impacts of road transportation on environment: A spatial approach. // Desalination, 226, 1-3(2008), pp. 279-288. DOl: 10.1016/j.desal.2007.02.111

[35] Tewolde, M. G.; Cabral, P. Urban sprawl analysis and modeling in Asmara, Eritrea. Remote Sensing. 3, 10(2011), pp. 2148-2165. DOI: 10.3390/rs3102148

[36] Zheng, H. W.; Shen, G. Q.; Wang, H.; Hong, J. Simulating land use change in urban renewal areas: A case study in Hong Kong. // Habitat International 46(2015), pp. 23-34. DOI: 10.1016/j.habitatint.2014.10.008

\section{Author's address}

\section{Derya Ozturk, PhD}

Department of Geomatics Engineering

Ondokuz Mayis University

55139, Atakum, Samsun, Turkey

E-mail:dozturk@omu.edu.tr 